\title{
P-23口腔癌におけるテロメラーゼ活性の検討
}

○丸岡 由佳* - 黒川 英雄 ${ }^{*}$ - 原田 英光 ${ }^{* *}$-豊島 邦昭** ・梶山 稔*

$*$ 九歯大 $・ \square$ 外 $2, * *$ 九歯大・口解 2

\section{Detection of Telomerase Activity in Human Oral Cancer Cells and Tissues}

- Yuka Maruoka*, Hideo Kurokawa*, Hidemitsu Harada**, Kuniaki Toyoshima** and Minoru Kajiyama* (*Oral and Maxillofacial Surgery 2 and ${ }^{* *}$ Oral Anatomy 2, Kyushu Dental College)

Key words: Telomerase/Oral cancer/Non-RITRAP

\section{はじめに}

染色体末端にあるテロメア DNA は，細胞分裂のたび に短縮し，ある限界に達すると細胞は死滅する。しかし ある種の細胞は，テロメア DNAを合成する逆転写酵素 ・テロメラーゼをもつため, テロメア DNA の短縮が生 じない，近年，アイソトープと PCR 法を用いてテロメ ラーゼを高感度に検出する TRAP 法が開発された：そ の結果，多くのヒト正常体細胞組織では，テロメラーゼ 活性は陰性であるが，癌化に伴い，高率に陽性となるこ とが知られるようになった。ここで我々は，アイソトー プを用いないTRAP法として，銀染色法あるいは SYBR Green I 染色法によるテロメラーゼ活性の検出 を試みた。

\section{研究材料，方法}

研究対象は，培養細胞として口腔癌由来の $\mathrm{KB}, \mathrm{SCC}$ -25, OT, MBを, また, 子宮頸癌由来の HeLa,

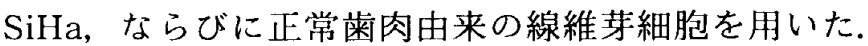
一方, 口腔癌 10 例, 白板症 3 例, 良性腫瘍 5 例の組織 を使用した。な抢対照として正常柬肉粘膜，正常唾液腺 組織 10 例を用いた。

テロメラーゼ活性の測定法は粗細胞抽出液を用い，培 養細胞では $2 \mu \ell$, 組織ではタンパク $20 \mu \mathrm{g}$ 相当量に調整 しアッセイに供した。 アッセイはプライマー上でテロメ ラーゼによりテロメア DNA を延長させ，PCR で増幅 を行ったのち．PCR 産物を電気泳動し，銀染色あるい はSYBR Green I ${ }^{\circledR}$ 染色による検出を行った.

\section{結果}

1. 銀染色法之 SYBR Green I ${ }^{\circledR}$ 染色法の比較

癌由来の培養細胞では, $10^{5}$ 個の細胞において, 全て テロメラーゼ活性が認められたが，正常組織由来の線維 牙細胞ではテロメラーゼ活性は認められたかった。そこ で培養癌細胞数を各々 $10^{5}, 10^{4}, 10^{3}, 10^{2}$ 個に調整して, テロメラーゼ活性の検出を行った。検出感度は銀染色の 方が SYBR Green 染色上りもわずかに良好であった が，タンパク再同時に染色されるためバックグラウンド が高かった。

2.組織内におけるテロメラーゼ活性

口腔癌組織では 10 例中 7 例, 白板症では 3 例中 2 例 にテロメラーゼ活性を認めたが，良性腫瘍，正常組織で はテロメラーゼ活性を認めなかった。

\section{まとめ}

1．アイソトープを用いずにテロメラーゼ活性を検出 する方法として銀染色法と SYBR Green 染色法を試み たところ，テロメラーゼ活性の測定には，銀染色法によ る検出が優れていた。

2. 本検出法は，口腔組織におけるテロメラーゼ活性 の测定に有用であった．今後は，テロメラーゼ活性の発 現や調整に関連すると思われる因子について検索する予 定である.

\section{参考文献}

Kim, N. W., Piatyszek, M. A., Prowse, K. R., Harley, C. B., West, M. D., Ho, P. L. C., Coviello, G. M., Wright, C. W. E., Weinrich, S. L. and Shay, J. W. : Specific Association of Human Telomerase Activity with Immortal Cells and Cancer. Science. 266 : 2011-2015, 1994 